\title{
Exotic biological control agents: a solution or contribution to arthropod invasions?
}

Ann E. Hajek ${ }^{1}$, Brett P. Hurley², Marc Kenis ${ }^{3}$, Jeffrey R. Garnas², Samantha J. Bush ${ }^{2}$, Michael J. Wingfield ${ }^{4}$, Joop C. van Lenteren ${ }^{5}$, Matthew J. W. Cock $^{6}$

${ }^{1}$ Department of Entomology, Cornell University, Ithaca, New York 14853-2601 USA e-mail: aeh4@ cornell.edu

${ }^{2}$ Department of Zoology and Entomology, Forestry and Agricultural Biotechnology Institute (FABI), University of Pretoria, Pretoria, 0002, South Africa

${ }^{3}$ CABI, 1 Rue des Grillons, 2800 Delémont, Switzerland

${ }^{4}$ Department of Microbiology and Pathology, Forestry and Agricultural Biotechnology Institute (FABI), University of Pretoria, Pretoria, 0002, South Africa

${ }^{5}$ Laboratory of Entomology, Wageningen University, P.O. Box 16, 6700AA, Wageningen, The Netherlands ${ }^{6}$ CABI, Bakeham Lane, Egham TW20 9TY, United Kingdom

Abstract Biological control is a valuable and effective strategy for controlling arthropod pests and has been used extensively against invasive arthropods. As one approach for control of invasives, exotic natural enemies from the native range of the pest are introduced to areas where control is needed. Classical biological control began to be used in the late 1800s and its use increased until, beginning in 1983, scientists began raising significant concerns and questions about nontarget and indirect effects that can be caused by these introductions. In recent years, similar issues have been raised about augmentative use of exotic natural enemies. Subsequently, international guidelines, national regulations and scientific methods being used for exotic natural enemies in biological control have changed to require appropriate specificity testing, risk assessment and regulatory oversight before exotic natural enemies can be released. National and international standards aimed at minimizing risk have increased awareness and promoted more careful consideration of the costs and benefits associated with biological control. The barriers to 
the implementation of classical and augmentative biological control with exotic natural enemies now are sometimes difficult and, as a consequence, the numbers of classical biological control programs and releases have decreased significantly. Based in part on this new, more careful approach, classical biological control programs more recently undertaken are increasingly aimed at controlling especially damaging invasive arthropod pests that otherwise cannot be controlled. We examine evidence for these revised procedures and regulations aimed at increasing success and minimizing risk. We also discuss limitations linked to the apparent paucity of postintroduction monitoring and inherent unpredictability of indirect effects.

Keywords Exotic biological control agents, nontarget effects, environmental safety, classical biological control, augmentative biological control, host range

\section{Introduction}

This paper focuses on the biological control of arthropods using arthropod biological control agents. Perhaps the earliest example of the use of biological control was in China where nests of predatory ants were moved in citrus orchards to control larval Lepidoptera (Huang and Yang 1987). In 1888-1889, the startlingly successful control of the cottony cushion scale (Icerya purchasi) by an exotic insect, the vedalia beetle (Rodolia cardinalis) imported from Australia (the area of origin of the scale) became such an accomplishment that a new era of biological control began, initially with greatest emphasis on classical biological control. Development of

new methods for pest control were rarely of primary importance during WWI and WWII except regarding control of arthropods threatening public health, and after WWII new synthetic 
chemical pesticides were widely used. However, by 1962 Rachel Carson's Silent Spring alerted the public to the environmental effects being caused by the excessive use of pesticides that was occurring. This encouraged a resurgence among entomologists in the development and use of biological control, in part as an alternative to chemical control and with a goal of protecting the environment (Greathead and Greathead 1992). These biological control strategies often employed exotic arthropods to control exotic arthropod pests. Use of biological control and resulting successes in control increased over time.

Although biological control gained much popularity as an alternative to use of insecticides, over time public priorities, perceptions and values began to change. Beginning in the 1980s and continuing for several decades since then, criticism was leveled at use of exotic arthropods in classical biological control and, more recently, augmentative biological control; the principal accusations were linked to negative impacts on biodiversity. Such scrutiny resulted in stricter regulation and more careful examination and oversight of potential and proposed biological control releases by regulatory bodies and practitioners alike. Increased focus on unintended consequences is undoubtedly a good thing. However, a side effect of this shift in attitude and approach has been a decline in use of biological control. The degree that this pendulum swing is warranted is worthy of evaluation, since the costs of inaction or delay with respect to biological control (e.g., elevated pesticide use, community and ecosystem consequences of invasive species) are nontrivial.

In this paper, we discuss the history of introductions of exotic natural enemies for control of arthropods and consider concerns related to potential environmental impacts of this approach. We also consider how these concerns have influenced the practice and use of biological control. Many of the claims of significant environmental effects due to agents released for biological 
control of arthropods are refuted and we argue that when used appropriately, this practice can provide an effective and environmentally responsible solution for control of invasive arthropods. We end by considering how biological control of arthropods is now moving forward in the face of the great need for the control of increasing numbers of invasive alien insects, and we encourage increasing post release evaluations to build data on the potential for direct and indirect nontarget effects.

The field of biological control includes several different strategies and many types of natural enemies, used against an equal diversity of pests (Hajek 2004; Cock et al. 2012). This review is focused principally on classical and augmentative biological control of arthropods using exotic arthropod natural enemies and the target pests themselves are often exotics. We refer readers to literature discussing similar concerns and resulting changes associated with risks and benefits related to biological control targeting weeds (e.g., McFadyen 1998; van Wilgen et al. 2013; Suckling and Sforza 2014).

\section{Classical biological control}

Use of classical biological control, first formally recorded in 1888-1889, generally refers to the introduction of natural enemies from the area of origin of a species to an area where this species has been introduced and is a pest with the goal of permanent establishment and control. As such, this method has predominantly been aimed at controlling invasive species. Although this might appear to be a rather restricted practice, the strategy has been used extensively. As of 2006, there have been 7,094 introductions involving 2,677 invertebrate biological control agents around the world (Cock et al. 2010). Analysis of the of the use of arthropod biological control 
agents in the database compiled for Cock et al. (2010) shows that biological control targets of these introductions have been primarily insect pests (79.9\%) and weeds (17.8\%), with $2.3 \%$ against mite pests (pathogens were not included in this database).

Biological control agents that have been used are predominantly predatory, parasitic and herbivorous insects but also include mites, nematodes, snails and a limited number of pathogens of invertebrates and plants (Cock et al. 2010; Hajek et al. 2007; Winston et al. 2014). Here, we focus on the use of exotic arthropod biological control agents to control arthropod pests. Spectacular successes have been achieved with classical biological control, sometimes using multiple agents in combination, but frequently success has only been partial or the introduced enemy has not become established after release (Cock et al. 2010). Since the 1950s, the success rate improved through to the 1980s (Greathead and Greathead 1992), and this trend has continued through to the 2000s (M.J.W. Cock unpublished data). Increasing success has been attributed in part to the change in approach from that used until the 1950s and 1960s when many of the potentially useful biological control agents were released to a more targeted approach that includes laboratory studies to confirm target suitability (Greathead and Greathead 1982). In addition, for some systems where the same pest had been released in many different countries, finding successful biological control agents resulted in multiple successes, as these natural enemies were used repeatedly.

Use of classical biological control requires foreign exploration for natural enemies that are then transported to a quarantine facility in a receiving country. Either prior to this or in the quarantine methods for rearing must be developed and resulting colonies of natural enemies must be cleaned of pathogens or parasites. The general biology and potential for control are typically evaluated (e.g., developmental time across a range of temperatures, adult feeding and mating 
behaviors and longevity). Testing a range of potential non-hosts, often selected based on relative phylogenetic and/or ecological proximity to the target pest, is a critical step. Only after necessary permits have been obtained can the natural enemy be released. The protocol is that the number of individuals released is based on only inoculating the new area and the introduced natural enemies will increase in response to populations of the pest.

Classical biological control has predominantly targeted economically important pests in agriculture and forestry although as numbers of invasive species are increasing (Aukema et al. 2010), more target pests are invasive species negatively affecting natural areas (Van Driesche et al. 2010; Van Driesche and Reardon 2014) or invasives impacting both natural and managed systems. One current example is the invasive emerald ash borer (Agrilus planipennis), accidentally introduced to North America from China, which is killing ash (Fraxinus spp.) trees that are both in urban plantings as well as in native North American and European forests. The classical biological control program being undertaken therefore impacts both natural as well as urban forests (Bauer et al. 2014).

\section{Augmentative biological control}

Augmentative biological control refers to periodic releases of biological control agents for control of economically important invertebrate pests. As part of augmentation, the inundative strategy involves releasing large numbers of natural enemies, with control enacted by the agents released. This is in contrast to an inoculative strategy that involves control by both the agents released, often early in a growing season before pest populations increase significantly, and generations of their offspring but without the assumption that permanent establishment and control will occur. The agents used may be native to the area, exotic but already established, or 
not established. Regardless of the strategy, augmentation often involves mass production of natural enemies by an industry that has formed for this purpose or, sometimes, field collection of natural enemies for subsequent release. The pests targeted often have worldwide distributions (i.e., are invasives) and the natural enemies that are used are frequently species that provide effective control and for which successful methods for mass production or collection have been developed.

Augmentative control has been used for more than 100 years. More than 230 species of invertebrate natural enemies (predominantly insects, mites and entomopathogenic nematodes) are sold for control of about 100 pest species, although about 30 species make up more than $90 \%$ of worldwide use (van Lenteren 2003; van Lenteren et al. 2011; van Lenteren 2012). Species of bacteria, fungi and viruses are also used for augmentative control. Some major examples of uses of augmentation include the egg parasitoids of the genus Trichogramma and the bacterium Bacillus thuringiensis for control of pests in field crops and releases of many different species of natural enemies to control many pests in greenhouse cultures (van Lenteren 2012).

\section{Negative effects of biological control of arthropods using exotic arthropod natural enemies}

Until the early 1980s, the introduction of exotic arthropod natural enemies to control arthropod pests was considered a very safe control strategy as it enabled pest control without use of synthetic chemical pesticides. However, following Howarth (1983), a serious debate in the scientific literature began to emerge regarding the environmental safety of introductions of exotic natural enemies (see below). This initially focused on the effects of classical biological control on nontarget organisms, with a recent shift to include augmentative biological control using exotic agents (van Lenteren et al. 2006; van Lenteren 2012). 


\section{Controversy regarding environmental safety of biological control using exotics}

From the 1950s through to the 1970s the numbers of introductions of parasitoids and predators via classical biological control programs reached all-time-highs (Greathead and Greathead 1992) (Fig. 1). However, there were occasional comments, often by systematists, that

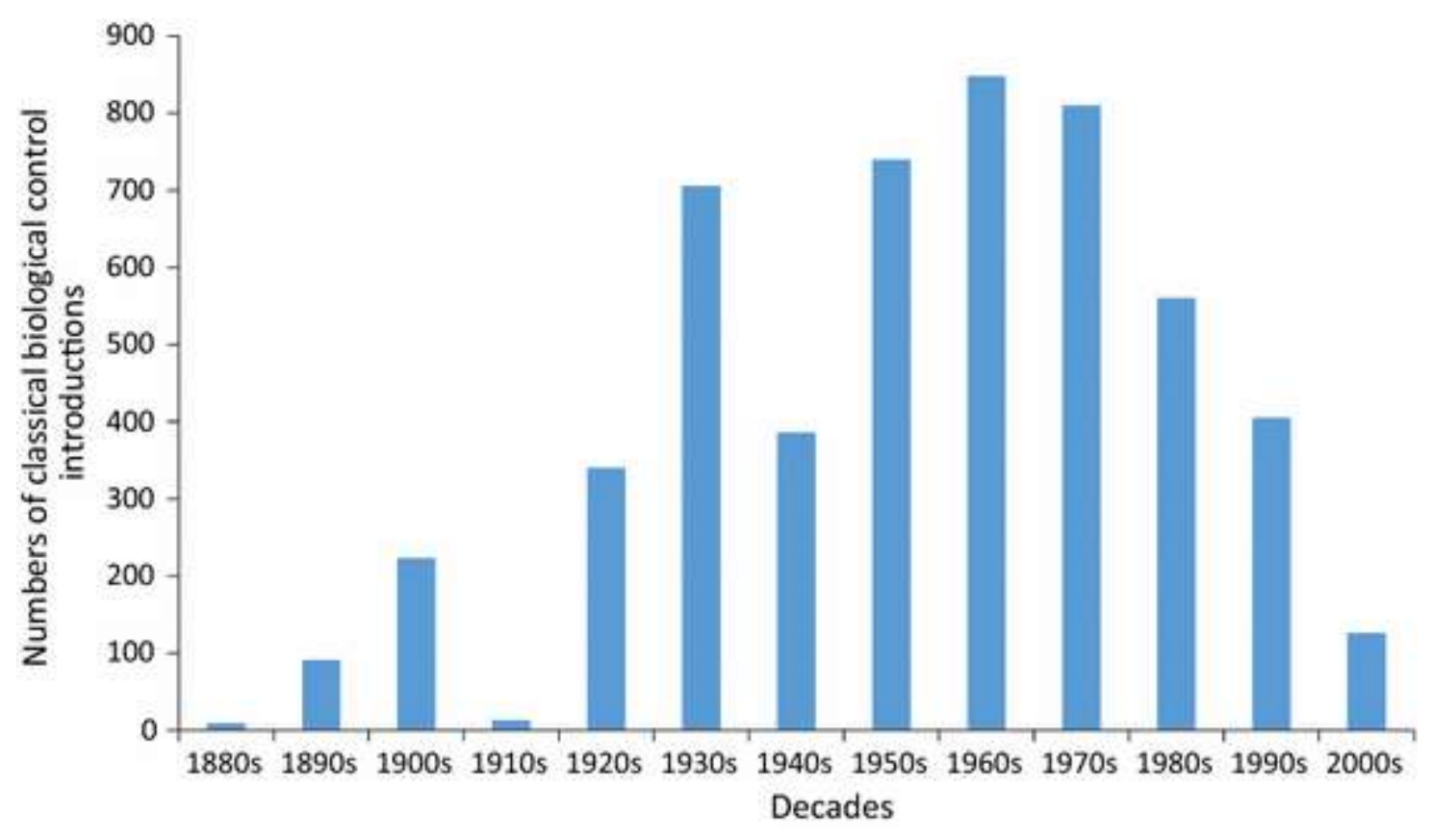

Figure 1. Numbers of classical biological control introductions of insect predators and parasitoids initiated against arthropod pests, from 1880-2010. Data preparation consistent with previous synthesis by Greathead and Greathead (1992), updated based on published information until the end of 2010. Although the numbers of introductions in the 2000s will increase as more work is published, projections suggest that the increase for this period will not be more than 25\% (MJWC unpublished data).

these introduced exotic species were also attacking native species. With the massive numbers of introductions being made to the islands of Hawaii, it is not surprising that a systematist in Hawaii raised alarms in the field of entomology in 1983 with a paper titled "Classical biocontrol: 
Panacea or Pandora's Box" (Howarth 1983). Papers that followed, about nontarget impacts (Samways 1988; Howarth 1991; Simberloff and Stiling 1996; Hawkins and Marino 1997) began a debate that intensified after publication of widely read and discussed papers on impacts of introduced weevils on native thistles in the North American Great Plains (Louda et al. 1997) and parasitic flies introduced against gypsy moth that also attacked native silkworms (Boettner et al. 2000). Many entomologists debated the beneficial versus detrimental aspects of classical biological control in the late 1990s and early 2000s (see Follett and Duan 2000; Samways 1997; Lockwood et al. 2001; Wajnberg et al. 2001; Louda et al. 2003; Pearson and Callaway 2003; Messing and Wright 2006). Scientists and governmental agencies began working toward establishing new methods and regulations for making decisions so that only environmentally safe exotic natural enemies would be introduced in the future (Delfosse 2005; Wright et al. 2005; Bigler et al. 2006; van Lenteren et al. 2006a).

Concerns about the safety of classical biological control predominantly reside in the specificity of the introduced natural enemy and its resulting effects on the ecosystem. Early in the growth in the discipline of biological control, it was considered positive for natural enemies to have broad host ranges, so that natural enemies could remain permanently established in an area even at low pest populations and then would be able to increase readily if the pest population increased. This approach was often driven by scientists whose primary goals were agricultural productivity and this view continues today in some areas. While agricultural production remains extremely important, today our knowledge of the value of biodiversity has also become more firmly established. The importance of maintaining functional native biotic communities and the ecosystem services that they sustain is also now considered of great 
importance (Van Driesche et al., 2010) by both practitioners and regulators of classical biological control.

Inundative and inoculative augmentation use both indigenous and exotic natural enemies. When using exotic natural enemies for augmentation, it is not expected that these will become permanently established in the areas of application, although there are examples where this has occurred (van Lenteren 2006; van Lenteren et al. 2008). From 1985 through 2000 there was a burgeoning greenhouse industry in Europe and North America and augmentative biological control grew significantly to support this industry (van Lenteren 2003). While some of the natural enemies used were released outdoors, most were only released indoors, but were able to escape from interior facilities. Over time, some of these natural enemies became established and a few have themselves become pests of concern. One species that is the focus of such issues related to both inundative augmentation and classical biological control is the multicolored Asian ladybird beetle, Harmonia axyridis. This is a voracious generalist predator that in Europe and North America has become a human nuisance along with contaminating grapes which leads to undesirable flavor in resulting wine and damaging fruit (Roy et al. 2007; Koch and Galvan 2008). However, the main controversy about the nontarget effects of the $H$. axyridis invasion has focused on the decreasing populations of native coccinellids that lose out to this superior predator (Roy et al., 2012).

In order to avoid environmental problems associated with biological control, van Lenteren et al. (2006a) proposed a method for risk assessment, to decide which natural enemies of arthropod pests were of greatest concern regarding future nontarget impacts. In the mid-2000s, two books emphasizing 'nontarget effects' of arthropod biological control also revealed a change in attitude toward avoiding future environmental disruption caused by biological control 
introductions (Van Driesche and Reardon 2004; Bigler et al. 2006). Environmental impacts have now been recognized as impacts directly affecting native species and impacts that indirectly affect native species or ecosystems.

\section{Direct effects}

Direct effects include situations where exotic biological control agents directly impact native species (Fig. 2a). Exotic biological control agents have been found attacking nontarget species in their regions of introduction. This is especially true for predators and parasitoids that were released before approximately 1950, when impacts on nontarget species and communities were not a central concern and governmental oversight about the safety of releases had not been well established. For example, Hawkins and Marino (1997) reported that 16\% of the 313 parasitoids of holometabolous hosts introduced into North America were found to parasitize nontarget hosts on occasion. In a more regional analysis, a 1988 survey of classical biological control introductions to Hawaii found that $22 \%$ of 243 classical biological control agents had been reported attacking nontarget hosts (Funasaki et al. 1988). In this latter survey, all agents showing negative effects had been introduced before 1967. On the island of Kauai, a survey of parasitoids attacking Lepidoptera documented that parasitoid species introduced for classical biological control were the principal species attacking native lepidopterans, but no nontarget impact was documented for any parasitoid species released after 1945 (Henneman and Memmott 2001). However, occasional nontarget feeding on native hosts or prey does not imply an impact at the population or community level. Many such records may represent trivial environmental impacts, although proper evaluation of impacts by observation or experimentation has seldom been done. In fact, very few cases of quantified negative ecological effects on populations or 

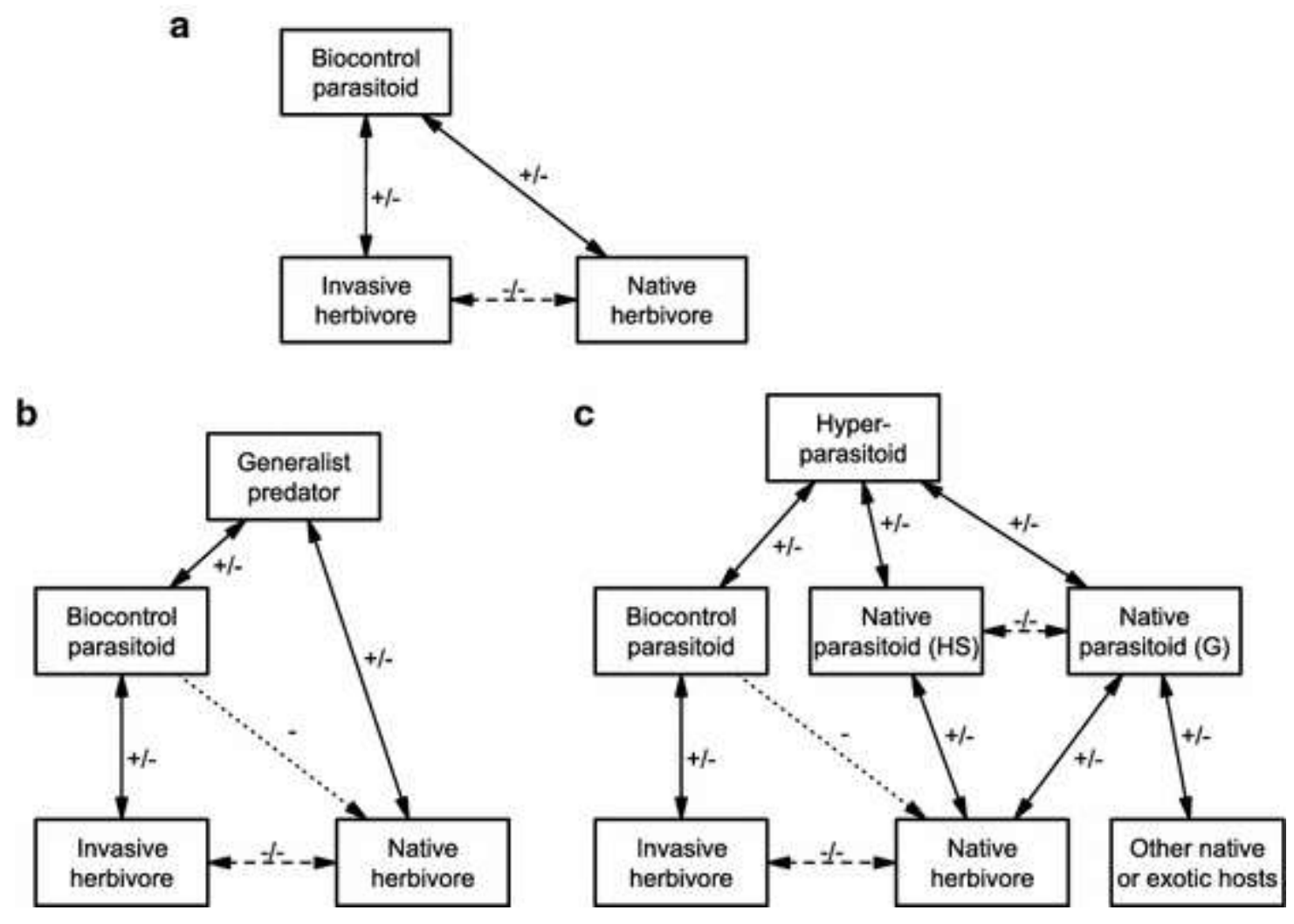

Figure 2. Interactions demonstrating cascading effects linked to the addition of a hypothetical parasitoid to a trophic web, including: direct effects due to nontarget host use by a biological control parasitoid (a); indirect effects mediated by a generalist predator that feeds across trophic levels, including on the biological control parasitoid (b); and, indirect effects mediated by a third trophic level (in this case a hyperparasitoid) that feeds broadly on various parasitoids in the system (c). In all three communities there exists the possibility of apparent competition within each trophic level. Solid lines are direct effects (e.g., predation or competition), dotted lines are indirect effects, and dashes lines convey the potential for direct effects (competition) or indirect (apparent competition). HS=host specific; $\mathrm{G}=$ generalist.

communities of native species, or on ecosystem functions, have been documented for the more than 2000 exotic biological control agents introduced worldwide against arthropod pests. In their extensive world review of ecological effects of invasive insects, Kenis et al. (2009) found evidence of measured nontarget effects on native biodiversity in eight biological control agents 
Table 1. Non-exhaustive list of insects introduced for classical biological control against arthropod pests for which direct non-target effects at the population level have been documented or are suspected. See Lynch and Thomas 2000, van Lenteren et al. 2006, Parry 2008 and Kenis et al. 2009 for details and primary references. The same authors also mention other, less conclusive cases.

\begin{tabular}{|c|c|c|c|c|c|}
\hline Species (Family) & Non target species & Impact $^{\top}$ & Mechanism $^{2}$ & $\begin{array}{l}\text { Non- } \\
\text { target }^{3} / \\
\text { habitat }^{4}\end{array}$ & Location \\
\hline \multicolumn{6}{|l|}{ Parasitoids } \\
\hline Aphidius ervi (Braconidae) & Praon pequadorum (Braconidae) & $\mathrm{D}$ & C & $\mathrm{N} / \mathrm{E}$ & USA \\
\hline Bessa remota (Tachinidae) & Two moths & $E$ & $\mathrm{~Pa}$ & $\mathrm{~N} / \mathrm{N}$ & Fiji \\
\hline Cales noacki (Aphelinidae) & Parasitoids & $\mathrm{D}$ & $\mathrm{C}$ & $\mathrm{N} / \mathrm{N}$ & Italy \\
\hline Compsilura concinnata (Tachinidae) & Saturnidae and possibly parasitoids & D & $\mathrm{Pa}, \mathrm{C}$ & $\mathrm{N} / \mathrm{N}$ & USA \\
\hline Copidosoma floridanum (Encyrtidae) & Trichogrammatoidea & $\mathrm{S}$ & $\mathrm{C}$ & $\mathrm{N} / \mathrm{A}$ & New Zealand \\
\hline Cotesia flavipes (Braconidae) & Parasitoids & $\mathrm{S}$ & $\mathrm{C}$ & $E / A$ & Trinidad and Brazil \\
\hline Lysiphlebus testaceipes (Braconidae) & Parasitoids & $\mathrm{D}$ & $\mathrm{C}$ & $\mathrm{N} / \mathrm{A}$ & Italy \\
\hline Tamarixia dryi (Eulophidae) & Trioza litseae (Triozidae) & $\mathrm{S}$ & $\mathrm{Pa}$ & $E / A$ & La Réunion \\
\hline Torymus sinensis (Torymidae) & Torymus beneficus (Torymidae) & $\mathrm{D}$ & $\mathrm{H}$ & $\mathrm{N} / \mathrm{N}$ & Japan \\
\hline Aphytis holoxanthus (Aphelinidae) & Aphytis costalimai (Aphelinidae) & $\mathrm{S}$ & $\mathrm{C}$ & $\mathrm{N} / \mathrm{A}$ & USA and Brazil \\
\hline \multicolumn{6}{|l|}{ Predators } \\
\hline Coccinella septempunctata (Coccinellidae) & Coccinellidae & $\mathrm{D}$ & IGP, C & $\mathrm{N} / \mathrm{N}$ & USA \\
\hline Harmonia axyridis (Coccinellidae) & Coccinellidae & $\mathrm{D}$ & $\mathrm{IGP}, \mathrm{C}$ & $\mathrm{N} / \mathrm{N}$ & North America \\
\hline
\end{tabular}

${ }^{1}$ Impact: E: apparent eradication; D: Decline due to the biological control agent documented and quantified by primary studies; S:

Decline due to the biological control agent suspected but not ascertained or not measured (see Kenis et al. 2009).

${ }^{2}$ Most likely mechanisms: C: Competition for resources with other natural enemies; IGP: intra-guild predation; H: Hybridization; Pa: parasitism.

${ }^{3}$ Non-target categories: N: at least some important non-target species are native species; E: the main non-target species are exotic.

${ }^{4}$ Habitat where the effect occurs: N: effect occurs in natural or semi-natural habitats, including forests; A: effect has been studied only in agricultural or urban habitats, or on non-native plants. 
only (six parasitoids and two predators) (impact noted as E and D in Table 1). Lynch and Thomas (2000), van Lenteren et al. (2006a) and Parry (2008) listed and classified a few more cases of nontarget effects, but these include effects on non-native species (e.g. other invasive arthropods), or cases where nontarget effects are suspected but not verified (Table 1).

Interestingly, critics of classical biological control often state that the lack of evidence for nontarget effects caused by many introduced biological control agents is due to lack of sampling or attention to this issue (e.g., Samways 1997; Lockwood 2000). In contrast, some proponents of biological control tend to consider that the lack of evidence for nontarget effects reflects ecologically insignificant impacts on nontarget species. The reality is rather that more nontarget ecological effects are likely to be found under closer examination, at least at the habitat or microhabitat levels. The same is true, however, for the ecological effects of all exotic arthropods, including those against which biological control has been applied or considered (Kenis et al. 2009). Thus, when assessing the nontarget impacts of biological control projects, it is essential to balance the impact of the biological control agent or agents with that of the target pests and the damage that could be caused by other control strategies likely to be used (Van Driesche et al. 2008).

In principle, nontarget impacts would be more likely to be found with older introductions, when polyphagous natural enemies were introduced without consideration of such effects. However, when long periods of time have passed since an introduction, it becomes complicated to assess the exact impact of exotic natural enemies because the necessary quantitative data on native species populations before the introduction, or in non-invaded areas, are often lacking (Kenis et al. 2009). Another difficulty in assessing nontarget effects of exotic natural enemies, and alien arthropods in general, is the large spectrum of impact mechanisms, both direct and 
indirect, that need to be considered (Parry 2008; Kenis et al. 2009). It is also difficult to directly compare old versus new introductions due to the confounding ecological and landscape contexts and given the real possibility that lag effects could potentially be obscuring impacts of more recent introductions.

The risk of direct effects on organisms related to the target pest has received by far the most attention in the scientific literature, as well as from practitioners and regulatory bodies (White et al. 2006). One of the most famous historical examples is that of the tachinid fly Bessa remota, which has been suggested to have caused the extinction of the target species, the zygaenid coconut moth Levuana iridescens, in Fiji but also of a nontarget native zygaenid moth, Heteropan dolens (Tothill et al. 1930; Howarth 1991; Kuris 2003). However, the most recent assessment (Hoddle 2006) considers that this needs to be properly assessed with a comprehensive survey before coming to such a conclusion. Another well-known case is the parasitic fly, Compsilura concinnata, introduced in the USA to control the gypsy moth, Lymantria dispar, at the beginning of the $20^{\text {th }}$ century (Boettner et al. 2000). This parasitoid contributed to larval mortality in the target host and accidentally also controlled another invasive pest, the brown-tail moth Euproctis chrysorrhoea. However, $C$ concinnata has also been found attacking at least 200 species of at least 15 families of native Lepidoptera, and three families of sawflies (Arnaud 1978), demonstrably reducing populations of at least a subset of these (Kellogg et al. 2003; Elkinton and Boettner 2012).

Interestingly, although several intentional introductions of polyphagous predators such as the cane toad, Rhinella marina (= Bufo marinus), or the rosy wolfsnail, Euglandina rosea, have caused catastrophic direct effects on biodiversity (Cowie 2001; Shine 2010), we are not aware of any arthropod predator introduced for biological control that has caused a quantified effect on 
nontarget prey that is closely related to the target prey species. The two best-known examples of detrimental arthropod biological control predators are the coccinellids $H$. axyridis and Coccinella septempunctata introduced against aphids in various parts of the world. These species have caused declines not only of aphids but also of other aphidophagous species, in particular other coccinellids (Evans 2004; Roy et al. 2012). It is not clear however whether the declines have been caused by competition for food or intraguild predation, or also by both species occurring independently or together. In some areas, it is thought that these species were not purposefully released but spread on their own as invasives (Roy et al. 2012).

A principal tool in the biological control toolbox designed to minimize or eliminate nontarget effects is host specificity testing. Parasitoids are currently favored for classical biological control as many are reasonably host specific and, partly for that reason, are the most widely used group of agents. However, few parasitoids are completely monophagous and, according to some accounts, most parasitoids will 'drift' to attack other species occasionally (Parry 2008). Also among introductions of parasitoids, there are several measurable cases of displacements of native parasitoids, although no large-scale extinction has yet been reported (see cases of Lysiphlebus testaceipes, Cales noaki, Aphidius ervi, C. concinnata and others (Lynch and Thomas 2000; van Lenteren et al. 2006a; Parry 2008; Kenis et al. 2009).

Introduced natural enemies can also theoretically affect populations of native, closelyrelated species or sub-species through hybridization. The most cited example is Torymus sinensis parasitoids introduced in Japan against the chestnut gall wasp Dryocosmus kuriphilus. This introduced parasitoid may have caused a severe reduction in population densities of the native Torymus benefices (Yara 2006), possibly in part due to hybridization. The hybridization hypothesis was based on laboratory production of hybrids. However, subsequent molecular 
studies suggest that hybridization rarely occurs in the field and probably plays a minor role in displacement of T. benefices (Yara et al. 2007).

\section{Indirect effects}

Indirect effects can be defined as population feedbacks mediated through the interaction of two or more biotic agents to produce measurable changes in community structure or ecosystem function (McCoy and Frank 2010; Pearson and Callaway 2003). Indirect effects from biological control may also potentially impact ecosystems but they have received considerably less attention than direct effects, most probably because they are less obvious and more difficult to study (Holt and Hochberg 2001; Pearson and Callaway 2003). This section focuses specifically on changes in population densities, or the nature and strength of interactions within communities where exotic biological control agents have been released.

Indirect effects can take many forms, particularly in complex communities where the number of potential interactions are many (Clough 2012). Perhaps the most commonly cited form is apparent competition (Pearson and Callaway 2003). Apparent competition refers to the phenomenon where there is an inverse relationship between the abundances of two or more species (typically ecologically similar species of the same trophic level), mediated by a third organism, typically a shared natural enemy. Positive numerical responses in predator or parasitoid species to an abundant prey can result in spillover and suppression of nontarget organisms, even across habitat boundaries (in the case of mobile enemies with strong searching abilities). The phenomenon is labeled "apparent competition" since the reciprocal changes in population densities as a result of shared enemies often mimic expectations under resource competition (Holt and Hochberg 2001). Apparent competition can occur as a consequence of 
direct, nontarget effects (Fig. 2a). However, even in the case of host specific biological control agents, complex community feedbacks can cause apparent competition indirectly, through one or more links in a trophic web (Fig. 2b,c). In the case of biological control using insects, there are few empirical examples showing apparent competition (Thomas et al. 2004). In a rare experimental test of apparent competition in the field (though not strictly in the context of biological control) van Nouhuys and Hanski (2000) added 250-300 Cotesia glomerata cocoons to within $20 \mathrm{~cm}$ of Glanville fritillary, Melitaea cinxia, larval nests across three experimental and three control populations on the island of Alland in Finland. The Glanville fritillary serves as the host for another Cotesia parasitoid, C. melitaearum, but there is no overlap in host use (and therefore no opportunity for competition) between the two species. In experimental sites, densities of the generalist hyperparasitoid (Gelis agilis) were elevated, resulting in dramatic reductions in $C$. melitaearum metapopulations, including local extinction in some sites.

Indirect effects do not always lend themselves to classification and may rather be idiosyncratic to the organisms involved. For example, biological control of the alfalfa weevil using a parasitoid wasp is enhanced by the presence of pea aphids that provide a carbohydrate subsidy to adult wasps in the form of honeydew (Evans and England 1996). Ladybird beetles are effective predators of pea aphids and have the indirect consequence of reducing wasp efficacy against the weevil. Such feedback among exotic, independently introduced agricultural pests and their biological control agents illustrates the complexity of these systems and the potential for unintended consequences even in a simplified, man-made ecosystem.

Additional possibilities for indirect effects that have received even less attention but nevertheless warrant consideration include symbiont sharing (including endosymbionts hypothesized to confer resistance to parasitism (Hansen et al. 2007)), or spillover or 
amplification of native or co-introduced pathogens (see Wingfield et al. this issue). Subtle effects on phenology or behavior of target (or nontarget) insects are also plausible, though little empirical data exist to corroborate such changes in response to biological control releases. There is, however, abundant evidence that natural enemies can influence host plant choice in affected insects (Price et al. 1980), which could have cascading effects on multiple aspects of community and ecosystem function.

Opinions on the importance of indirect effects vary, with some authors characterizing them as at least as important as direct effects (Pearson and Callaway 2003) while others suggest that their importance may be exaggerated, especially with respect to the biological control of insects (Thomas et al. 2004). In fact, the reduction of an undesirable species can itself have unintended consequences on communities and ecosystems. For example, reductions in densities of native aphids due to generalist ladybird predators have been implicated in the decline in specialist parasitoid wasps that depend on aphid-produced honeydew (Evans 1996). Clearly, the range of possible ecological feedbacks predicted by theory (Holt and Hochberg 2001) and the accumulating list of examples (Pearson and Callaway 2003, 2005; Simberloff 2012), suggest that vigilance is warranted. Importantly, both direct and indirect effects may be strongest during the transient phases post-introduction when populations can reach levels well above equilibrium densities, thus amplifying the strength of some interactions (Holt and Hochberg 2001), although temporarily. Predicting and/or testing for indirect effects is challenging (Karban 1994; Simberloff 2012) but recommendations call for greater focus on communities rather than pairwise interactions in both pre- and post-establishment monitoring. 


\section{Changes in regulations and methods for classical biological control}

The shift in public opinion toward the importance and protection of biodiversity has resulted in changes in the regulations for the use of classical biological control of arthropods, and this consequently influences methods surrounding the evaluation and release of agents. Many of these changes are related to concerns about nontarget effects of released biological control agents. Australia's Quarantine Act of 1908 was one of the first pieces of legislation for invertebrate biological control agents, although this Act was used to ensure that introduced biological control agents would not become agricultural pests and nontarget effects on noneconomically valuable species were not considered (Hunt et al. 2008). It was only in the 1980's, once perceptions on the potential risks of releasing exotic biological control agents against arthropods were starting to change, that practitioners in Australia started to conduct host specificity tests of exotic arthropods to be released for control of arthropods (Kuhlmann and Mason 2003; Sands and Van Driesche 2003). In the meantime, host specificity testing had already become a common practice in weed biological control, mainly because herbivorous agents were perceived as potentially more damaging to agriculture than agents for controlling arthropods (van Klinken 2000). In the 1990s, Australia and New Zealand were the first countries to change their legislation to address the potential for nontarget impacts in biological control programs against arthropods (Barratt and Ferguson 2000; Cameron et al. 2013; Van Driesche and Hoddle 1997). The requirement for assessment of risks to nontarget species has since been adopted by other countries and organizations including Switzerland, Netherlands, United Kingdom and South Africa (van Lenteren et al. 2006a; Bale 2011). In International Standards for Phytosanitary Measures (ISPM) No. 3, the International Plant Protection Convention (IPPC) sets out Guidelines for the Export, Shipment, Import and Release of Biological Control Agents and 
other Beneficial Organisms (FAO 2006) based on a pest risk assessment approach. The 168 member countries of the IPPC are expected to follow these guidelines if they do not have their own legislation to at least this standard.

Various methods have been developed in order to meet the requirements for nontarget testing, most notably with regard to the selection of nontarget species and the experiments required to test their suitability as potential hosts. The main approach to selecting potential nontarget species for weed biological control is the phylogenetic centrifugal method, which assumes phylogenetic conservatism in host use and therefore focuses on testing species most closely related to the target species. The centrifugal approach has also been largely adopted by researchers and practitioners for control of arthropod pests. However, in the case of parasitoids, taxonomy is a less successful predictor of host range (Cameron et al. 2013). To improve the utility of such assays, potential nontarget species should also include ecologically similar species, e.g., arthropods that share habitats, phenology and/or niches with other hosts, irrespective of being taxonomically related (Hogendoorn 2013; Kuhlmann and Mason 2003; Van Driesche and Hoddle 1997; van Lenteren et al. 2006a). Likewise, it is typically worthwhile to also examine effects on other introduced biological control agents (Van Driesche et al. 2008; van Lenteren et al. 2006a), species of economic importance (Hogendoorn 2013; Van Driesche and Hoddle 1997; van Lenteren et al. 2006a), as well as species of conservation concern such as rare and endangered species (Van Driesche and Hoddle 1997; van Lenteren et al. 2006a). Comprehensive experimental evaluation of attractiveness, preference and suitability of alternate hosts or prey would generally be performed under controlled conditions. Such tests would typically include choice tests, no-choice tests, sequential tests and other similar methods. Often using a combination of methods increases robustness of observed outcomes and improves 
confidence in the results (Barratt et al. 2010; Hopper 2001; Van Driesche and Hoddle 1997; Van Driesche et al. 2008; van Lenteren et al. 2006b). Recent criticisms of laboratory tests to assess host specificity as being too simplistic have resulted in a move toward including other studies of biological control agents to assess their potential risk. These include understanding the ecological and not only the physiological host range through studies of dispersal ability, life table analysis, trophic web studies, the use of experimental populations and incorporating climate matching (Boyd and Hoddle 2007; Hopper 2001; Louda et al. 2003).

Post-release studies to confirm the establishment of the agent, but also to confirm the absence of nontarget effects, have been included in the requirements of some regulatory bodies (De Clerck-Floate et. al. 2006). However, such studies can be logistically challenging, appropriate methods are still uncertain and funding can be an obstacle. In particular, the time after introduction to conduct post-release studies is difficult to determine due to differential timing in establishment and dispersal of different species of insects. Initial range expansion may not be linear and may instead undergo 'jump dispersal' or the new introduction could enter an 'eclipse period' or 'lag phase' of low densities where Allee effects occur, where population growth trajectories keep populations low or where density after release falls below a detection threshold (Lockwood et al. 2013), possibly because of high dispersal rates from the release area (Henne et al. 2007).

Besides regulations requiring host specificity testing, another major change affecting the introduction of biological control agents has been regulations affecting the export of potential biological control agents from their area of origin. The Convention on Biological Diversity in 1992 established that each country has sovereignty over its biodiversity. Subsequent meetings in Bonn in 2008 and Nagoya in 2010 developed agreements to define how a country's genetic 
resources (including biological control agents) may be accessed. This includes Access and Benefit Sharing (ABS) as defined under the Nagoya Protocol, under which each country is now expected to prepare its own legislation and regulations. In order to export potential biological agents, the country of origin may require prior informed consent and agreement about how to share any benefits from access to these genetic resources (Cock et al. 2010). These regulations play an important role in ensuring that a country's biodiversity is not exploited without sharing the benefits, but can have a negative outcome when access to and exploitation of natural enemies for biological control is limited due in part to the absence of regulations, difficulties in navigating the regulation processes, differing regulations for different countries and lengthy permitting processes. This has in extreme cases led to the cessation of biological control programs (Coutinot et al. 2013) and it seems likely to impact negatively on biological control programs in the future. Since classical biological control is usually conducted by governmental agencies for no profit and the augmentative biological control industry gains little profit, the goals of these rulings will not be met via collections of exotic biological control agents. Therefore, an exception is being suggested for biological control (and non-commercial scientific research in general), in which access to potential biological control agents would be facilitated by legislation rather than impeded (van Lenteren et al. 2011).

Biological control agents do not recognize political borders. Thus a conflict of interest may develop when an agent released in one country poses a potential risk to another country. This could be due to nontarget effects on species not present in the country of release and/or not considered in host specificity tests. In response to these concerns there have been a few guidelines and agreements within regions on the consultation of intended releases. In the IPPC ISPM 3 Guidelines for the Export, Shipment, Import and Release of Biological Control Agents 
and other Beneficial Organisms the responsible authorities are encouraged to communicate details of intended releases that may affect neighboring countries (IPPC 2006). The USA, Canada and Mexico jointly developed "Guidelines for Petition for Release of Exotic Entomophagous Agents for the Biological Control of Pests," a North American standard for submissions to release biological control agents whereby each member country can make recommendations on whether the proposed biological control agent should be released (de Clerck-Floate et al. 2006). The South American Common Market (Mercosur) has developed phytosanitary regulations for member countries that include the regulation, import and release of biological control agents, where biological control research programs are required to consider potential risks to other countries in that region (Coutinot et al. 2013). Regulation in the European Union has been at the discretion of member countries (Bale 2011), with the lack of unity in part due to concerns by member countries that new regulations would be costly and time consuming (Bale 2011; Hunt et al. 2008; Kelly 2012; Loomans 2007). However, organizations and initiatives such as ERBIC (Evaluating Environmental Risks of Biological Control Introductions), REBECA (Regulation of Biological Control Agents), IOBC-WPRS (International Organization for Biological Control - West Palaearctic Regional Section) and EPPO (European Plant Protection Organization) are seeking to harmonize regulatory requirements within the EU (Bale 2011).

\section{Changes occurring in the use of biological control}

A decided change occurred over the past century, with a move away from use of generalist exotic predators and parasitoids for biological control introductions. Numbers of classical biological control introductions began decreasing in the 1980s and this trend continues 
in the $21^{\text {st }}$ century (Fig. 1). The global decline was most likely initiated by reduced use of exotic biological control agents in the USA, by far the largest user of exotic biological control agents (Cock et al. 2010), in response to concerns about nontarget impacts. The decreasing use of exotic biological control agents continued, as these concerns spread to other parts of the world. The drop in the rate of biological control deployment is particularly stark when compared with the continuing or increasing rates of introductions of invasives in many systems during the same period (Aukema et al. 2010; Roques et al. 2009). As concerns grew, practitioners developed new protocols and regulatory agencies started to create new and stricter regulations. Under the new scrutiny, fewer of the natural enemies found in foreign exploration surveys were considered suitably host-specific to prepare a petition for their release. In addition, once new regulations or plans were in place, the host specificity testing that was required took much more time and effort than previously, which also decreased the number of natural enemies proposed for release and slowed the process.

Complicating the picture regarding the cause for the decline in classical biological control introductions, beginning in 2002, Access and Benefit Sharing (see above) also acted to slow use of new exotic arthropods for biological control. The extent that this development versus environmental safety issues has affected the decline in numbers of introductions of exotic natural enemies in the 2000s is not known but certainly both of these issues probably together led to the low number of releases in the last decade.

The use of exotic species in augmentative biological control has also changed drastically during the past 15 years in response to issues of environmental safety and Access and Benefit Sharing. For example, there is clearly concern about nontarget effects of exotic coccinellids that have been used for biological control; the case of $H$. axyridis has especially been highlighted 
although some of the problems have been of great concern in areas where $H$. axyridis has never been released but only arrived via dispersal. Even in North America and Europe, where $H$. axyridis has been released, accidental introductions have probably played a major role in the invasion (Lombaert et al. 2011). In fact, the majority of arthropod natural enemies have been introduced accidentally as part of the global movement of invasive species and not as purposeful biological control introductions (e.g., Snyder and Evans 2006; Roy et al. 2011). Increasingly, indigenous natural enemies are being evaluated for their potential use for augmentative biological control, in part to avoid complex legislation and registration. This has changed the picture for use of new exotic species in augmentative biological control, particularly in Europe: the majority of natural enemies newly introduced to the market in the period $1960-1999$ were exotics, whereas from 2000 onwards more than $75 \%$ on of the new species were of indigenous origin (van Lenteren 2012).

\section{The future of biological control using exotic natural enemies against arthropods}

Exotic natural enemies have been used extensively in the past for biological control of arthropods, resulting in decreased damage from pests in crops and native ecosystems along with diminished reliance on chemical or other control strategies. Unfortunately, from the 1980s to the 2000s, purported nontarget effects due to exotic parasitoids and predators introduced for classical biological control cast a negative light on use of exotics in biological control. However, extensive analyses have demonstrated that nontarget effects impacting native species at the population level are rare when compared with the number of introductions that have occurred (Lynch and Thomas 2000; van Lenteren et al. 2006; Parry 2008; Kenis et al. 2009). This is consistent with the fact that there are no native species of arthropods that have been negatively 
impacted by biological control agents and are included in the list of threatened species

maintained by the International Union for Conservation of Nature (Collen et al. 2012; IUCN 2015).

Concerns about nontarget effects at the population level, caused by using arthropod natural enemies for augmentative biological control have only more recently been investigated but seem to be of concern mainly for generalist, non-indigenous natural enemies whose climatic requirements allow them to establish in the region of treatment. Biological control agents of this type are no longer proposed for use in several countries like the UK and the Netherlands (Bale 2011).

Despite the overall lack of significant nontarget impacts, with the notable exception of $H$. axyridis, concern has been voiced about the potential for negative impacts on biodiversity, arising from the use of exotics in biological control of arthropods (Van Driesche et al. 2008). Researchers in the field of biological control need to actively engage the scientific community and the public to regain their trust through demonstrating that significant changes have been made to address these concerns, including using fewer agents, using agents of demonstrated host specificity, evaluating risks to biodiversity and ecosystem services, improved and appropriate procedures, regulation and consultation, and post release follow-up to detect possible nontarget effects (Table 2). In addition, stakeholders should be included in the decision making process regarding potential releases to ensure a transparent process and that information is accurately communicated (Warner and Kinslow 2013). Care must always be advocated, and to do so the costs and benefits of control options should be clearly understood. 
Table 2. General overview of practices related to risk management for classical and augmentative biological control of insects before versus after emphasis on environmental concerns began. ${ }^{1}$

\begin{tabular}{|c|c|c|}
\hline & Pre-environmental concerns & Post-environmental concerns \\
\hline $\begin{array}{l}\text { Host specificity of biological } \\
\text { control agents }\end{array}$ & $\begin{array}{l}\text { Broad host range usually } \\
\text { considered to be desirable for } \\
\text { augmentative biological control } \\
\text { and even sometimes for classical } \\
\text { biological control }\end{array}$ & $\begin{array}{l}\text { Agents selected are host specific, } \\
\text { in particular for classical biological } \\
\text { control. In augmentative biological } \\
\text { control, some agents with broader } \\
\text { host ranges are used if they have } \\
\text { shown no direct or indirect } \\
\text { negative effects for a long time }\end{array}$ \\
\hline $\begin{array}{l}\text { Selection of biological control } \\
\text { agents }\end{array}$ & $\begin{array}{l}\text { Any biological control agent } \\
\text { associated with the target might } \\
\text { be used }\end{array}$ & $\begin{array}{l}\text { A small number of more host- } \\
\text { specific biological control agents } \\
\text { are selected and evaluated (but } \\
\text { see above for species with broader } \\
\text { host ranges) }\end{array}$ \\
\hline Nontarget effects on biodiversity & $\begin{array}{l}\text { Limited concern for nontarget } \\
\text { effects }\end{array}$ & $\begin{array}{l}\text { Concern for nontarget effects; } \\
\text { Recognition of the importance of } \\
\text { biodiversity and ecosystem } \\
\text { services }\end{array}$ \\
\hline Regulations & $\begin{array}{l}\text { Limited regulation of safety of } \\
\text { releases }\end{array}$ & $\begin{array}{l}\text { Strong regulation of safety of } \\
\text { releases }\end{array}$ \\
\hline $\begin{array}{l}\text { Consultation with neighboring } \\
\text { countries }\end{array}$ & $\begin{array}{l}\text { Little or no consultation with } \\
\text { neighboring countries }\end{array}$ & $\begin{array}{l}\text { Regional agreements/ } \\
\text { consultations in some regions }\end{array}$ \\
\hline $\begin{array}{l}\text { Elimination of pathogens } \\
\text { contaminating biological control } \\
\text { agents }^{2}\end{array}$ & $\begin{array}{l}\text { Pathogen contaminants often not } \\
\text { managed except as a culturing } \\
\text { issue }\end{array}$ & $\begin{array}{l}\text { Elimination of pathogens } \\
\text { contaminating biological control } \\
\text { agents routine }\end{array}$ \\
\hline Taxonomic precision $^{2}$ & $\begin{array}{l}\text { Partially or inadequately identified } \\
\text { biological control agents often } \\
\text { used }\end{array}$ & $\begin{array}{l}\text { If no name available, biological } \\
\text { control agents documented with } \\
\text { voucher specimens (and today } \\
\text { barcoded) }\end{array}$ \\
\hline Post-release studies & Very few conducted & Few conducted \\
\hline
\end{tabular}

${ }^{1}$ No specific years are listed as these changes were made at different times by different organizations around the world.

${ }^{2}$ IPPC 2006; Fisher and Andrés 1999. 
It appears that much of the stigma associated with classical biological control exists as a legacy of releases that were executed 65 or more years ago when, reflecting the value of society at the time, there was little recognition of the existence or importance of nontarget effects. Risk assessment for nontarget effects was not a requirement for biological control of arthropods in the past but its importance is now clearly recognized and accepted. The assessment and host range testing required to address governmental legislation, while improving environmental safety, have contributed to decreasing the numbers of new exotic biological control agents released each year. The Access and Benefit Sharing legislation is also affecting options to find and use exotic biological control agents (Cock et al. 2010) and this is a matter for serious concern.

There are many biological control success stories (e.g., Clausen 1978; Cock 1985; Cameron et al. 1989; Waterhouse and Sands 2001; Neuenschwander et al. 2003; Mason and Gillespie 2013) and we believe that these outweigh those examples where this approach to pest management has had negative impacts. In many cases, the negative impacts that have emerged were not expected. Now that nontarget effects are recognized as an issue, the risks can be minimized based on research to better understand the processes involved. We argue strongly for substantially increased investment in biological control research that leads to rigorous evidencebased policy formulation. For example, there should be much greater levels of investment to capture the power of modern technologies such as molecular genetic tools in order to accurately identify biological control agents (and their target pests) and to understand their population genetics (See Garnas et al., this issue).

Regulations regarding the use of biological control agents are inconsistent in terms of the countries where they are applied; rules are often applied in one country but not in effect in bordering countries. This is especially relevant in continents composed of many countries (often 
with porous boundaries) and where regulations can vary from rigorous to non-existent. Thus, introductions into one country without care can have negative impacts elsewhere which in turn may damage the reputation of an otherwise very positive technology. This is a situation that requires attention and supports a call for global rather than national strategies to promote opportunities in biological control (Garnas et al. 2012).

Biological control has provided and should continue to provide many positive outcomes for dealing with damaging invasive alien insect pests (see Wingfield et al. 2015). It is unfortunate that a negative perception of this important technology has emerged and this could clearly result in lost opportunities in the future. It is necessary to engage the public and other stakeholders more closely in the work being done, the risks involved and the potential benefits that could accrue from successful actions. Along these same lines, there should also be greater levels of investment in research to evaluate population level effects on targets as well as nontargets and thus to better understand the risks as well as the opportunities offered by biological control.

\section{Acknowledgements}

This paper had its origin at a workshop on "Drivers, impacts, mechanisms and adaptation in insect invasions" hosted by the DST-NRF Centre of Excellence for Invasion Biology in Stellenbosch, South Africa, in November 2014. We thank Drs. M. J. Samways, J. Gould and R. Van Driesche and two anonymous reviewers for valuable suggestions on an early version of this manuscript. 


\section{References}

Arnaud Jr PH (1978) A Host-Parasite Catalog of North American Tachinidae (Diptera). USDA

Miscellaneous Publication No. 1319, 860 pp.

Aukema JE, McCullough DG, Von Holle B, Liebhold AM, Britton K and Frankel SJ (2010) Historical accumulation of nonindigenous forest pests in the continental United States. BioScience 60:886897

Babendreier D, Bigler F and Kuhlmann U (2005) Methods to assess nontarget effects of invertebrate biological control agents of arthropod pests. BioControl 50:821-870

Babendreier D (2007) Pros and cons of biological control. In: Nentwig W (ed) Biological Invasions, pp 403-418. Springer, Berlin

Bale J (2011) Harmonization of regulations for invertebrate biocontrol agents in Europe: progress, problems and solutions. J Appl Entomol 135:503-513

Barratt BIP and Ferguson CM (2000) Predicting the risk from biological control agent introductions: a New Zealand approach. In: Follett PA, Duan JJ (eds) Nontarget Effects of Biological Control, pp 59-75. Kluwer Academic Publishers, Dordrecht, NL

Barratt BIP, Howarth FG, Withers TM, Kean JM and Ridley GS (2010) Progress in risk assessment for classical biological control. Biol Control 52:245-254

Barratt BIP, Oberprieler RG, Ferguson CM and Hardwick S (2005) Parasitism of the lucerne pest Sitona discoideus Gyllenhal (Coleoptera: Curculionidae) and non-target weevils by Microctonus aethiopoides Loan (Hymenoptera: Braconidae) in south-eastern Australia, with an assessment of the taxonomic affinities of non-target hosts of M. aethiopoides recorded from Australia and New Zealand. Austral J Entomol 44:192-200

Barratt BIP, Oberprieler RG, Barton DM, Mouna M, Stevens M, Alonso-Zarazaga MA, Vink CJ and Ferguson CM (2012) Could research in the native range, and non-target host range in Australia, have helped predict host range of the parasitoid Microctonus aethiopoides Loan (Hymenoptera: 
Braconidae), a biological control agent introduced for Sitona discoideus Gyllenhal (Coleoptera: Curculionidae) in New Zealand? BioControl 57:735-750

Barron MC, Barlow MD and Barratt BIP (2003) Non-target parasitism of the endemic New Zealand red admiral butterfly (Bassaris gonerilla) by the introduced biological control agent Pteromalus puparium. Biol Control 27:329-335

Bauer LS, Duan JJ and Gould JR (2014) Emerald ash borer. In: Van Driesche R, Reardon R (eds) The Use of Classical Biological Control to Preserve Forests in North America, pp 189-209. United States Department of Agriculture, Forest Service, Morgantown, WV, FHTET-2013-2

Bigler F, Babendreier D and Kuhlmann U (2006) Environmental Impact of Invertebrates for Biological Control of Arthropods: Methods and Risk Assessment. CABI, Wallingford, UK, 299 pp

Boettner GH, Elkinton JS, Boettner CJ (2000) Effects of a biological control introduction on three nontarget native species of saturniid moths. Conserv Biol 14:1798-1806

Boyd EA and Hoddle MS (2007) Host specificity testing of Gonatocerus spp. Egg-parasitoids used in a classical biological control program against Homalodisca vitripennis: a retrospective analysis for nontarget impacts in southern California. Biol Control 43:56-70

Brodeur J (2012) Host specificity in biological control: insights from opportunistic pathogens. Evol Appl $5: 470-480$

Brown PMJ, Ingels B, Wheatley A, Rhule EL, De Clercq P, Leeuwen T and Thomas A (2015) Intraguild predation by Harmonia axyridis (Coleoptera: Coccinellidae) on native insects in Europe: molecular detection from field samples. Entomol Sci 18:130-133

Cameron PJ, Hill RL, Bain J and Thomas WP (1989) A review of biological control of invertebrate pests and weeds in New Zealand 1874 to 1987. Technical Communication No. 10, CAB International Institute of Biological Control, CAB International, Farnham Royal, UK.

Cameron PJ, Hill RL, Teulon DAJ, Stukens MAW, Connolly PG and Walker GP (2013) A retrospective evaluation of the host range of four Aphidius species introduced to New Zealand for the biological control of pest aphids. Biol Control 67:275-283 
Charles JG, Forgie SA, Chhagan A and Edwards RD (2015) Field study demonstrates that exotic parasitoids (Hymenoptera: Encyrtidae) of mealybugs (Hemiptera: Pseudococcidae) are absent from a native forest habitat in New Zealand. BioControl 60:13-25

Clausen CP (1978) Introduced parasites and predators of arthropod pests and weeds: a world review. Agricultural Handbook No. 480. United States Department of Agriculture, Washington DC, USA. Clough Y (2012) A generalized approach to modeling and estimating indirect effects in ecology. Ecology 93:1809-15

Cock, M.J.W. (1985) A review of biological control of pests in the Commonwealth Caribbean and Bermuda up to 1982. Technical Communication No. 9, Commonwealth Institute of Biological Control, Commonwealth Agricultural Bureaux, Farnham Royal, UK.

Cock MJW, van Lenteren JD, Brodeur J, Barratt, BIP, Bigler F, Bolckmans K, Cônsoli FL, Haas F, Mason PG and Parra JRP (2010) Do new Access and Benefit Sharing procedures under the Convention on Biological Diversity threaten the future of biological control? BioControl 55:199218

Cock MJW, Biesmeijer JC, Cannon RJC, Gerard PJ, Gillespie D, Jiménez JJ, Lavelle PM and Raina SK (2012) The positive contribution of invertebrates to sustainable agriculture and food security. CAB Rev: Perspec Agric, Vet Sci, Nutr Natl Res 7(43), 27 pp.

Collen B, Bohm M, Kemp R and Baillie JEM (2012) Spineless: Status and Trends of the World's Invertebrates. Zoological Society of London, UK.

Cory J and Myer J (2000) Direct and indirect ecological effects of biological control. Trends Ecol Evol $15: 137-139$

Coutinot D, Briano J, Parra JRP, De Sá LAN and Cônsoli FL (2013) Exchange of natural enemies for biological control: is it a rocky road? - The road in the Euro-Mediterranean Region and the South American common market. Neotrop Entomol 42:1-14

Cowie RH (2001) Can snails ever be effective and safe biocontrol agents? Internatl J Pest Mgmt 47:23-40 
De Clercq P, Mason PG and Babendreier D (2011) Benefits and risks of exotic biological control agents. BioControl 56:681-698

De Clerck-Floate RA, Mason PG, Parker DJ, Gillespie DR, Broadbent AB and Boivin G (2006) Guide for the importation and release of arthropod biological control agents in Canada. Pest Management Centre, Agriculture and Agrifood Canada, Minister of Supply and Service Canada, Ottawa, 60 pp Delfosse ES (2005) Risk and ethics in biological control. Biol Control 35:319-329

Duan JJ and Messing RH (2000) Evaluating nontarget effects of classical biological control: fruit fly parasitoids in Hawaii as a case study. In: Follett PA, Duan JJ (eds) Nontarget Effects of Biological Control, pp 95-109. Kluwer Acad Publ, Boston, MA

Elkinton JS and Boettner GH (2012) Benefits and harm caused by the introduced generalist tachinid, Compsilura concinnata, in North America. BioControl 57:277-288

Evans EW (2004) Habitat displacement of North American ladybirds by an introduced species. Ecology $85: 637-647$

Evans EW and England S (1996) Indirect interactions in biological control of insects: pests and natural enemies in alfalfa. Ecol Appl 6:920-930

Fisher TW and Andrés LA (1999) Quarantine: concepts, facilities and procedures. In: Bellows TS, Fisher TW (eds) Handbook of Biological Control, pp 103-124. Academic Press, San Diego, CA

Follett PA and Duan JJ (eds) (2000) Nontarget Effects of Biological Control. Kluwer Acad Publ, Dordrecht, NL

Funasaki GY, Lai PY, Nakahara LM, Beardsley JW, Ota AK 1988. A review of biological control introductions in Hawaii: 1890 to 1985. Proc Hawaiian Entomol Soc 28:105-160

Garnas JR, Hurley BP, Slippers B and Wingfield MJ (2012) Biological control of forest plantation pests in an interconnected world requires greater international focus. Internatl J Pest Manag 58:211-223

Greathead DJ and Greathead AH (1992) Biological control of insect pests by insect parasitoids and predators: the BIOCAT database. Biocon News Info 13:61N-68N 
Hajek AE (2004) Natural Enemies: An Introduction to Biological Control. Cambridge Univ Press, Cambridge, UK, 396 pp

Hajek AE, McManus ML and Delalibera Junior I (2007) A review of introductions of pathogens and nematodes for classical biological control of insects and mites. Biol Control 41:1-13

Hansen AK, Jeong G, Paine TD and Stouthamer R (2007) Frequency of secondary symbiont infection in an invasive psyllid relates to parasitism pressure on a geographic scale in California. Appl Environ Microbiol 73:7531-7535

Hawkins BA and Marino PC (1997) The colonization of native polyphagous insects in North America by exotic parasitoids. Oecologia 112:566-571

Henne DC, Johnson SJ and Cronin JT (2007) Population spread of the introduced red imported fire ant parasitoid, Pseudacteon tricuspis Borgmeier (Diptera: Phoridae), in Louisiana. Biol Control 42:97-104.

Henneman ML and Memmott J (2001) Infiltration of a Hawaiian community by introduced biological control agents. Science 293:1314-1316

Hoddle MS (2001) Classical biological control of arthropods in the $21^{\text {st }}$ century. In: Van Driesche RG (ed) Proceedings of the International Symposium on Biological Control of Arthropods, Honolulu, Hawaii, 14-18 January 2002, pp 3-16. United States Department of Agriculture, Forest Service, Morgantown, WV, FHTET-2003-05, 573 pp.

Hoddle MS (2004) Restoring balance: using exotic species to control invasive exotic species. Conserv Biol 18:38-49

Hoddle MS (2006) Historical review of control programs for Levuana iridescens (Lepidoptera: Zygaenidae) in Fiji and examination of possible extinction of this moth by Bessa remota (Diptera: Tachinidae). Pacif Sci 60:439-453

Hogendoorn K, Keller MA and Baker G (2013) Preparedness for Biological Control of High-Priority Arthropod Pests. Grape and Wine Research Development Corporation, University of Adelaide, Adelaide, NSW, 75 pp 
Holt RD and Hochberg M (2001) Indirect interactions, community modules and biological control: A theoretical perspective. In: Wajnberg E, Scott JK and Quimby PC (eds) Evaluating Indirect Ecological Effects of Biological Control, pp 13-37. CABI, Wallingford, UK

Hopper KR (2001) Research needs concerning nontarget impacts of biological control introductions, pp 39-56. In: Wajnberg E, Scott JK and Quimby PC (eds) Evaluating Indirect Ecological Effects of Biological Control, pp 39-56. CABI, Wallingford, UK

Howarth FG (1983) Classical biocontrol: panacea or Pandora's box. Proc Hawaiian Entomol Soc 24:239244

Howarth FG (1991) Environmental impacts of classical biological control. Annu Rev Entomol 36:485509

Huang HT and Yang P (1987) The ancient cultured citrus ant. Bioscience 37:665-671

Hunt EJ, Kuhlmann U, Sheppard A, Qin TK, Barratt BIP, Harrison L, Mason PG, Parker D, Flanders RV and Goolsby J (2008) Review of invertebrate biological control agent regulation in Australia, New Zealand, Canada and the USA: recommendations for a harmonised European system. J Appl Entomol 132:89-123

IPPC (International Plant Protection Convention) (2006) Guidelines for the export, shipment, import and release of biological control agents and other beneficial organisms (2005). International Standards for Phytosanitary Measures No 3, Food and Agriculture Organisation of the United Nations, Rome. 32 pp

IUCN (International Union for Conservation of Nature) (2015) The IUCN Red List of Threatened Species. Version 2015-3. 〈http://www.iucnredlist.org>. [Accessed on 19 September 2015]

Johnson MT, Follett PA, Taylor AD and Jones VP (2005) Nontarget impact of biological control and invasive species on the nontarget native Hawaiian koa bug. Oecologia 142:529-540

Karban R, Hougen-Eitzmann D and English-Loeb G (1994) Predator-mediated apparent competition between two herbivores that feed on grapevines. Oecologia 97:508-511 
Kaufman LV and Wright MG (2009) The impact of exotic parasitoids on populations of a native Hawaiian moth using life table studies. Oecologia 159:295-304

Kaufman LV and Wright MG (2010) Parasitism of a Hawaiian endemic moth by invasive and purposely introduced Hymenoptera species. Environ Entomol 39:430-439

Kellogg SK, Fink LS and Brower LP (2003) Parasitism of native luna moths, Actias luna (L.)

(Lepidoptera: Saturniidae) by the introduced Compsilura concinnata (Meigen) (Diptera:

Tachinidae) in central Virginia, their hyperparasitism by trigonalid wasps (Hymenoptera:

Trigonalidae). Environ Entomol 32:1019-1027

Kelly J (2012) A review of biological control policy: Northern Ireland and Ireland. Prepared as part of Invasive Species Ireland. The Northern Ireland Environmental Agency and the National Parks and Wildlife Service, 58pp.

Kenis M, Auger-Rozenberg MA, Roques A, Timms L, Péré C, Cock MJW, Settele J, Augustin S and Lopez-Vaamonde C (2009) Ecological effects of invasive alien insects. Biol Invasions 11:21-45

Koch RL and Galvan TL (2008) Bad side of a good beetle: the North American experience with Harmonia axyridis. BioControl 53:23-35

Kuhlmann U and Mason PG (2003) Use of field host range surveys for selecting candidate nontarget species for physiological host specificity testing of entomophagous biological control agents, $\mathrm{pp}$ 370-377. In: Van Driesche RG (ed) Proceedings of the $1^{\text {st }}$ International Symposium on Biological Control of Arthropods, January 14-18, 2002. United States Department of Agriculture, Forest Service, Morgantown, WV, FHTET-2003-05, 573 pp.

Kuris AM (2003) Did biological control cause extinction of the coconut moth, Levuana iridescens, in Fiji? Biol Invasions 5:133-141

Lockwood JA (2000) Nontarget effects of biological control: what are we trying to miss? In: Follett PA, Duan JJ (eds) Nontarget Effects of Biological Control, pp. 15-30. Kluwer Acad Publ, Dordrecht, NL 
Lockwood JA, Howarth FG and Purcell MF (eds) (2001) Balancing Nature: Assessing the Impact of Importing Non-Native Biological Control Agents (an International Perspective). Thomas Say Publications in Entomology, Entomol Soc Amer, Lanham, Maryland, USA, 130 pp.

Lockwood JL, Hoopes MF and Marchetti MP (2013) Invasion Ecology, $2^{\text {nd }}$ edn. Wiley-Blackwell, Oxford, UK, 444 pp.

Lombaert E, Guillemaud T, Thomas CE, Handley LJL, Li J, Wang S, Pang H, Goryacheva I, Zakharov IA, Jousselin E, Poland RL, Migeon A, van Lenteren J, De Clercq P, Berkvens N, Jones W and Estoup A (2011) Inferring the origin of populations introduced from a genetically structured native range by approximate Bayesian computation: case study of the invasive ladybird Harmonia axyridis. Molec Ecol 20:4654-4670

Loomans AJM (2007) Regulation of invertebrate biological control agents in Europe: review and recommendations in its pursuit of a harmonised regulatory system. Report EU project REBECA (Regulation of Biological Control Agents). The Netherlands, $26 \mathrm{pp}$

Louda SM, Kendall D, Connor J and Simberloff D (1997) Ecological effects of an insect introduced for the biological control of weeds. Science 277:1088-1090

Louda SM, Pemberton RW, Johnson MT and Follett PA (2003) Nontarget effects-The Achilles' heel of biological control? Retrospective analyses to reduce risk associated with biocontrol introductions. Annu Rev Entomol 48:365-396

Lynch LD and Thomas MB (2000) Nontarget effects in the biocontrol of insects with insects, nematodes and microbial agents: the evidence. Biocontr News Info $21: 117 \mathrm{~N}-130 \mathrm{~N}$

Mason PG and Gillespie DR (eds) (2013) Biological Control Programmes in Canada, 2001-2012. CABI, Wallingford, UK

McCoy E and Frank J (2010) How should the risk associated with the introduction of biological control agents be estimated? Agric For Entomol 12:1-8

McFadyen REC (1998) Biological control of weeds. Annu Rev Entomol 43:369-393 
Messing RH and Wright MG (2006) Biological control of invasive species: solution or pollution? Front Ecol Environ 4:132-140

Neuenschwander P, Borgemeister C and Langewald J (2003) Biological control in IPM systems in Africa. CABI Publishing, Wallingford, UK

Parry D (2008) Beyond Pandora's Box: quantitatively evaluating non-target effects of parasitoids in classical biological control. Biol Invasions 11:47-58

Pearson DE and Callaway RM (2003) Indirect effects of host-specific biological control agents. Trends Ecol Evol 18:456-461

Pearson DE, Callaway RM (2005) Indirect nontarget effects of host-specific biological control agents: implications for biological control. Biol Control 35:288-298

Pearson DE and Callaway RM (2008) Weed-biocontrol insects reduce native-plant recruitment through second-order apparent competition. Ecol Appl 18:1489-1500

Price P, Bouton C, Gross P, McPheron BA, Thompson JN and Weis AE (1980) Interactions among three trophic levels: influence of plants on interactions between insect herbivores and natural enemies. Annu Rev Ecol Syst 11:41-65

Roques A, Rabitsch W, Rasplus J-Y, Lopez-Vaamonde C, Nentwig W and Kenis M (2009) Alien Terrestrial Invertebrates of Europe. In: Hulme PE, Nentwig W, Pyšek P, Vilà M (eds) DAISIE: Handbook of Alien Species in Europe, pp. 63-79. Springer, Dordrecht, NL

Roy HE and Wajnberg E (eds) (2007) From Biological Control to Invasion: The Ladybird Harmonia axyridis as a Model Species. Springer, Dordrecht, NL, 287 pp

Roy HE, Roy DB and Roques A (2011) Inventory of terrestrial alien arthropod predators and parasites established in Europe. BioControl 56:477-504

Roy HE, Adriaens T, Isaac NJB, Kenis M, Onkelinx T, San Martin G, Brown PMJ, Hautier L, Poland R, Roy DB, Comont R, Eschen R, Frost R, Zindel R, Van Vlaenderen J, Nedvěd O, Ravn HP, Grégoire JC, de Biseau JC and Maes D (2012) Invasive alien predator causes rapid declines of native European ladybirds. Divers Distrib 18:717-725 
Samways MJ (1988) Classical biological control and conservation: Are they compatible? Environ Conserv 15:349-354

Samways MJ (1997) Classical biological control and biodiversity conservation: What risks are we prepared to accept? Biodivers Conserv 6:1309-1316

Sands D and Van Driesche R G (2003) Host range testing techniques for parasitoids and predators. In:

Van Driesche RG (ed) Proceedings of the First International Symposium on Biological Control of Arthropods: January 14-18, 2002, pp 41-53. United States Department of Agriculture, Forest Service, Morgantown, WV, FHTET-2003-05, 573 pp.

Selfridge JA, Parry D and Boettner GH (2007) Parasitism of barrens buck moth Hemileuca maia Drury in early and late successional pine barrens habitats. J Lepid Soc 61:213-221

Shine R (2010) The ecological impact of invasive cane toads (Bufo marinus) in Australia. Q Rev Biol $85: 253-291$

Simberloff D (2012) Risks of biological control for conservation purposes. BioControl 57:263-276

Simberloff D and Stiling P (1996) How risky is biological control? Ecology 77:1965- 1974

Snyder WE and Evans EW (2006) Ecological effects of invasive arthropod generalist predators. Annu Rev Ecol Evol Syst 37:95-122

Strong DR (1997) Fear no weevil? Science 277:1058-1059

Suckling DM and Sforza RFH (2014) What magnitude are observed non-target impacts from weed biocontrol? PLoS One 9:e84847

Thomas MB, Casula P and Wilby A (2004) Biological control and indirect effects. Trends Ecol Evol 19:61

Tothill JD, Taylor THC and Paine RW (1930) The Coconut Moth in Fiji-a History of its Control by Means of its Parasites. Imperial Bureaux of Entomology, London

Van Driesche RG and Hoddle M (1997) Should arthropod parasitoids and predators be subject to host range testing when used as biological control agents? Agric Human Val 14:211-226 
Van Driesche R, Hoddle M and Center T (2008) Control of Pests and Weeds by Natural Enemies. Blackwell Publishing Limited, Malden, MA, 473 pp

Van Driesche RG, Murray T and Reardon R (eds) (2004) Assessing Host Ranges of Parasitoids and Predators Used for Classical Biological Control: a Guide to Best Practice. United States Department of Agriculture, Forest Service, Morgantown, WV, FHTET-2004-04, 242 pp Van Driesche RG and Reardon R (eds) (2014) The Use of Classical Biological Control to Preserve Forests in North America. United States Department of Agriculture, Forest Service, Morgantown, WV, FHTET-2013-2, 414 pp

Van Driesche RG, Carruthers RI, Center T, Hoddle MS, Hough-Goldstein J, Morin L, Smith L, Wagner DL, Blossey B, Brancatini V, Casagrande R, Causton CE, Coetzee JA, Cuda J, Ding J, Fowler SV, Frank JH, Fuester R, Goolsby J, Grodowitz M, Heard TA, Hill MP, Hoffmann JH, Huber J, Julien M, Kairo MTK, Kenis M, Mason P, Medal J, Messing R, Miller R, Moore A, Neuenschwander P, Newman R, Norambuena H, Palmer WA, Pemberton R, Perez Panduro A, Pratt PD, Rayamajhi M, Salom S, Sands D, Schooler S, Schwarzländer M, Sheppard A, Shaw R, Tipping PW and van Klinken RD (2010) Classical biological control for the protection of natural ecosystems. Biol Control 54, Suppl. 1:S2-S33

van Klinken RD (2000) Host specficity testing: why do we do it and how can we do it better. In: Van Driesche RG, Heard TA, McClay A, and Reardon R (eds) Proceedings of Session: HostSpecificity Testing of Exotic Arthropod Biological Control Agents-The Biological Basis for Improvement in Safety, pp 54-68. United States Department of Agriculture, Forest Service, Morgantown, WV, FHTET-99-1, 95 pp

van Lenteren JC (ed) (2003) Quality Control and Production of Biological Control Agents: Theory and Testing Procedures. CABI, Wallingford, UK, $327 \mathrm{pp}$

van Lenteren JC (2012) The state of commercial augmentative biological control: plenty of natural enemies, but a frustrating lack of uptake. BioControl 57:1-20 
van Lenteren JC, Bale J, Bigler F, Hokkanen HMT and Loomans AJM (2006a) Assessing risks of releasing exotic biological control agents of arthropod pests. Annu Rev Entomol 51:609-634 van Lenteren JC, Cock MJW, Hoffmeister TS and Sands DPA (2006b) Host specificity in arthropod biological control, methods for testing and interpretation of the data. In: Bigler F, Babendreier D and Kuhlmann U (eds) Environmental Impact of Invertebrates for Biological Control of Arthropods: Methods and Risk Assessment, pp 38-63. CABI, Wallingford, UK

van Lenteren, JC, Loomans AJM, Babendreier D and Bigler F (2008) Harmonia axyridis: an environmental risk assessment for Northwest Europe. BioControl 53:37-54

van Lenteren J, Cock MJW, Brodeur J, Barratt BIP, Bigler F, Bolckmans K, Haas F, Mason PG and Parra JRP (2011) Will the convention on biological diversity put an end to biological control? Rev Bras Entomol 55:1-5

van Nouhuys S and Hanski I (2000) Apparent competition between parasitoids mediated by a shared hyperparasitoid. Ecol Lett 3:82-84

van Wilgen BW, Moran VC and Hoffmann JH (2013) Some perspectives on the risks and benefits of biological control of invasive alien plants in the management of natural ecosystems. Environ Mgmt 52:531-540

Wajnberg E, Scott JK and Quimby PC (eds) (2001) Evaluating Indirect Ecological Effects of Biological Control. CABI, Wallingford, UK, 288 pp

Warner K and Kinslow F (2013) Manipulating risk communication: value predispositions shape public understandings of invasive species science in Hawaii. Public Understand Sci 22:203-218 Waterhouse DF and Sands DPA (2001) Classical biological control of arthropods in Australia. ACIAR Monograph No. 77. Australian Centre for International Agricultural Research, Canberra, Australia.

White EM, Wilson JC and Clarke AR (2006) Biotic indirect effects: a neglected concept in invasion biology. Divers Distrib 12:443-455 
Wingfield MJ, Brockerhoff EG, Wingfield BD and Slippers B (2015) Planted forest health: The need for a global strategy. Science 349:832-836

Winston RL, Schwarzländer M, Hinz HL, Day MD, Cock MJW and Julien MH (eds) (2014) Biological Control of Weeds: A World Catalogue of Agents and Their Target Weeds, 5th edition. United States Department of Agriculture, Forest Service, Morgantown, WV, FHTET-2014-04. 838 pp.

Wright M, Hoffmann M, Kuhar T, Gardner J, Pitcher SA (2005) Evaluating risks of biological control introductions: a probabilistic risk-assessment approach. Biol Control 35:338-347

Yara K (2006) Identification of Torymus sinensis and T. beneficus (Hymenoptera: Torymidae), introduced and indigenous parasitoids of the chestnut gall wasp Dryocosmus kuriphilus (Hymenoptera: Cynipidae), using the ribosomal ITS2 region. Biol Control 36:15-21

Yara K, Sasawaki T and Kunimi Y (2007) Displacement of Torymus beneficus (Hymenoptera: Torymidae) by $T$. sinensis, an indigenous and introduced parasitoid of the chestnut gall wasp, Dryocosmus uriphilus (Hymenoptera: Cynipidae), in Japanese chestnut fields: possible involvement in hybridization. Biol Control 42:148-154 